Acta regionalia et environmentalica 2

Nitra, Slovaca Universitas Agriculturae Nitriae, 2014, p. 59-63

\title{
IMPACT OF HUMAN ACTIVITY ON LOCAL CLIMATE CHANGE IN VEL'KÉ TUROVCE BY HEATING AND POSSIBILITIES FOR CARBON DIOXIDE DECREASE
}

\author{
Matej HUDEC
}

Slovak University of Agriculture in Nitra, Slovakia

\begin{abstract}
The paper is aimed at detecting $\mathrm{CO}_{2}$ emissions from heating process of households in Vel'ké Turovce. It offers solutions for $100 \%$ and $20 \%$ replacement of conventional fuels by solar collector systems. In the village, 242 households heat by natural gas during average length of 21 weeks a year. Average amount of energy consumed in heating process after conversion is $18,503.06 \mathrm{kWh}$ per household. For $100 \%$ replacement of natural gas, 63 units of vacuum tube solar collector type Watt CP C 9 are required. In average duration of 23 weeks a year, 12 households heat by brown coal with average consumption of 20,339.75 kWh. For complete replacement, 69 pieces of solar collectors are required. The remaining 18 households heat by firewood in average duration of 22 week a year. The consumption of one household represents in average 19,125.07 kWh. In this case, the replacement of $100 \%$ of firewood energy requires 65 pieces of solar panels. The amounts of saved $\mathrm{CO}_{2}$ emissions by collector system replacing $100 \%$ of natural gas represent $926,336.39 \mathrm{~kg}$ of $\mathrm{CO}_{2}$ for 242 households. For 12 households heated by brown coal, it represents $152,767.65 \mathrm{~kg}$ of saved $\mathrm{CO}_{2}$ emissions. Last but not least, $30,553.53 \mathrm{~kg}$ of $\mathrm{CO}_{2}$ represent the amount of saved $\mathrm{CO}_{2}$ emission for 18 households heating by firewood. Prices of collector systems in case of $100 \%$ replacement of conventional fuels would be $37,111.45 €$ for natural gas, 40,356.79€ for brown coal, and 38,203.23 $€$ in case of replacement of firewood.
\end{abstract}

Keywords: conventional fuels, $\mathrm{CO}_{2}$ emissions, emissions reduction, solar vacuum tube collectors, Velké Turovce

The aim of the paper is to provide possibilities of solving the problem of extensive releasing of carbon dioxide into atmosphere caused by heating process in households. It includes knowledge about heating methods in area of interest of Vel'ké Turovce. It also mentions the amounts of $\mathrm{CO}_{2}$ emissions released by heating process using solid fuels (natural gas, brown coal, and firewood) and natural gas as the most widespread method in the village. Based on results of calculations it was possible to dimension a solar collector system. This included dimensioning of $100 \%$ and $20 \%$ alternative for replacing conventional fuels. Subsequently, the calculation for replacement of all kind of fuels in each percentage alternative was made. This paper serves to achieve a thought about extending the proposed possibilities which can demote the load of atmosphere, as well as the other available methods leading to positive change of global problem. The question arises concerning the set system and legislation to promote the use of renewable energy sources in Slovakia as well as in the world. It is needed to consider the scale of the global problem, which may be even greater with current economic situation ruling the world. It is required to think about what is for us - as a human race - more important.

\section{Material and methods}

The area of interest is the municipality of Vel'ké Turovce. Input data for research were collected on basis of questionnaires. The questionnaire method was used in case of 60 households (30 using natural gas, 18 using firewood and 12 using brown coal). The questionnaire included 12 questions for the respondents. Based on the data from the questionnaire, average amount of used fuel in volume and mass units was converted to the average amount of energy that is needed for heating the above in kWh. Using conversion factors, conversion from the calculated average energy demand of household by the type of used fuel (kWh) to volume of produced $\mathrm{CO}_{2}$ emissions $(\mathrm{kg})$ per household was made. Due to knowledge about amount of energy demand of households that use one of type of conventional fuel, it was possible to accede to draft of solar collector system for heating purposes. To dimension the solar system, data based on table value were needed. According to the table for determining the total theoretical daily dose of sunlight

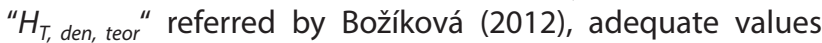
of table $\left(30^{\circ}\right)$ were chosen as the closest angle due to the best angle of inclination in the area of interest $\left(35^{\circ}\right)$. Based on values in table according to Matuška (2010), the relative duration of sunshine " $\tau_{r}$ " was determined consequently. The efficiency of a solar collector depends upon number of factors, such as amount of sunlight reaching the surface of collector, rainfall, and hence the cloudiness. The ambient temperature is significant in case of collector range of operating temperature. There are also significant factors as occurrence of snow and dust. Percentage expression of efficiency of solar vacuum collector " $\eta_{k}$ " was acquired on basis of data according to Duffie et al. (1991). Then, it was possible to calculate the amount of energy " $H_{T \text {, den }}$ " absorbed from the Sun by the collector surface during a day in a given month of heating season. After this step, the calculation of the amount of energy from the Sun and absorption surface of the solar collector " $q_{T \text {, mes }}$ " during each months of heating season from October to April followed. Due to various factors affecting the condition and operation characteristics of collector system, $12.5 \%$ (in value 0.125 ) losses on intake 
conduits " $p$ " were taken into account. This includes the sum of losses during heating season (cf. Petráš, 2009). The paper includes calculation that is necessary for configuring the solar collector system replacing $100 \%$ and $20 \%$ of household energetic demand in heating process in case of using each conventional fuel type. According to Ladener and Späte (2003), 20 \% replacement of energy supplied to the heating process by alternative source in household is considered to be standard ratio to the total amount of energy. Due to the need of whole meters in calculating the size of the active surface of a solar collector, the results were rounded up. Because the required area of solar collector depends on data about energy demand of households heated by given type of fuel, the calculation of the "S $S_{K}$ " value appeared form calculations. The resulting values of collector areas were rounded up. Subsequently, it is necessary to calculate the amount of solar collectors " $n$ " as a replacement of conventional fuels in case of all types of fuel types used in heating process.

Price calculation of the collector system was realized with respect to the purchase price of the kit type Watt Duo Mega for water and household heating purposes up to $300 \mathrm{~m}^{2}$ with 8 pieces of collectors type Watt CP C 9. The price of Watt Duo Mega system $(7,487.50 €$ including VAT) as well as individual collector type Watt C PC 9 (645.89 $€$ including VAT) was determined based on the exchange rate of the European Central Bank on 3.2.2013 for conversion from Polish Zloty (PLN) to Euro (Eur) (NBS, WATT2, WATT3, 2013). The final price was calculated with support of the government subsidy according to the Act no. 523/2004 coll. Due to this Act, it was possible to draw government financial support for installed solar collectors in case of houses and residential buildings in 2011. Financial support from the Slovak government was allowed for the area of solar collectors of above $8 \mathrm{~m}^{2}$ (in case of this research) by $50 €$ for each $1 \mathrm{~m}^{2}$ of installed absorption surface of collector. Therefore, the total price of the collector system is an equivalent of sum of collector system Watt Duo Mega ( $€ 7,487.50$ including VAT) with 8 pieces of collector type Watt C PC 9 and quantity of pieces of required collectors mentioned type (in price of $645.89 €$ including VAT) for replacement of conventional fuel type. In 2014, government support excludes the area of solar collectors system above $8 \mathrm{~m}^{2}$, therefore financial support is allowed only with solar system using area below $8 \mathrm{~m}^{2}$ in case of family houses.
In case of calculating the cost for heating of households using brown coal, it was counted with price of $90 €$ including VAT per ton. This price was set based on exploration of prices and it was chosen as the cheapest offer from two regional sellers (CENAE, 2013; Horváth, 2013; Oršula, 2013). In this case it was counted regarding the average consumption of $7.23 \mathrm{~m}^{3}$ of brown coal. In calculations, $\mathrm{m}^{3}$ was used as the unit of quantity for firewood. In case of offer on market, it is usually "prm" (spatial meter). Due to these different units, a conversion to "prm" was made. During the research, the firewood price was on the level of $39 €$ including VAT per "prm". This calculation counted with the volume of firewood $8.56 \mathrm{~m}^{3}$ (Jurovčík, 2008). Due to zero occurrence of households in tariff D4 (consumption above $6500 \mathrm{~m}^{3}$ ), the calculations take into account only tariffs D2 and D3 (SPP, 2013).

As a last issue of the research, investment return in both cases, for $100 \%$ and $20 \%$ replacement alternatives was calculated.

\section{Results and discussion}

Vel'ké Turovce has 272 households with 242 households using natural gas for heating purposes. Brown coal is used in 12 households and firewood in 18 households Figure 1 shows amount of fuel consumption in the households using three different types of fuel for heating purposes. There are households using natural gas consuming in average $18,503.06 \mathrm{kWh}\left(1741.65 \mathrm{~m}^{3}\right)$ during heating season. In case of households using brown coal, this amount reaches 20,339.75 kWh $\left(7.21 \mathrm{~m}^{3}\right)$. There are also households using firewood with average consumption of 19,125.07 kWh $\left(8.56 \mathrm{~m}^{3}\right)$.

The average amount of $\mathrm{CO}_{2}$ emissions produced by heating process during a heating season per household shown in Figure 2 reached the highest level of emissions in the village in case of natural gas. It was caused due to the highest number of households using natural gas (242). They produce $926,336.39 \mathrm{~kg}$ of $\mathrm{CO}_{2}$ per heating season. This amount was derivate according to information from 30 households using the same fuel, and made pattern to the general calculation. These 30 households produce in average $114,844.58 \mathrm{~kg}$ of $\mathrm{CO}_{2}$ emission. Households using brown coal produce $152,767.65 \mathrm{~kg}$ of $\mathrm{CO}_{2}$ emissions. In

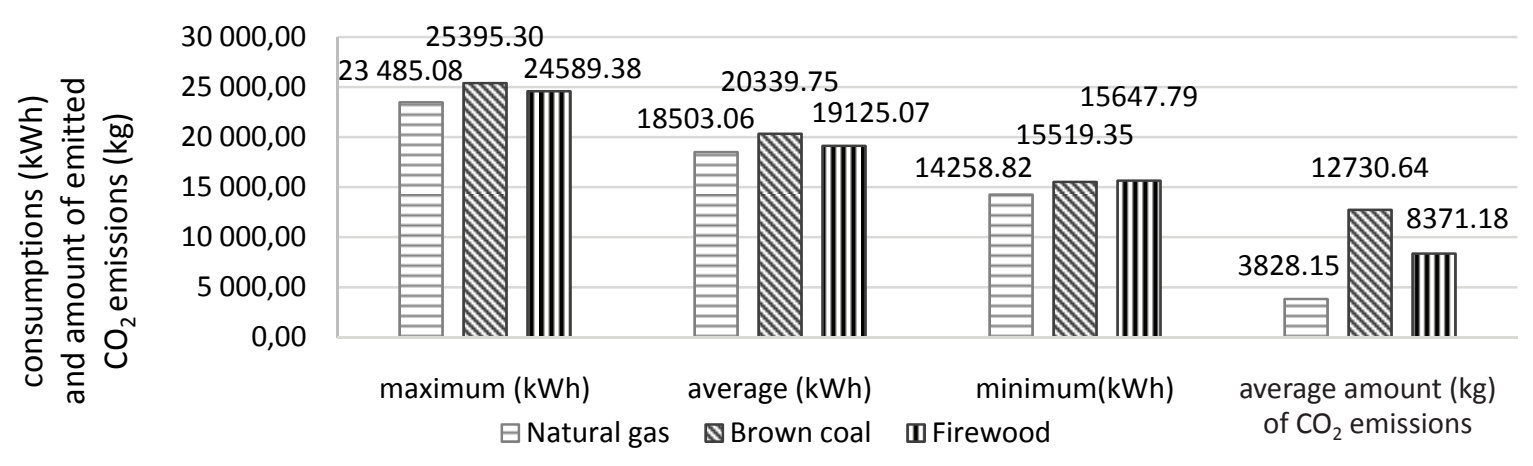

Figure 1 Energy consumption of households and average amount of emitted $\mathrm{CO}_{2}$ emissions 


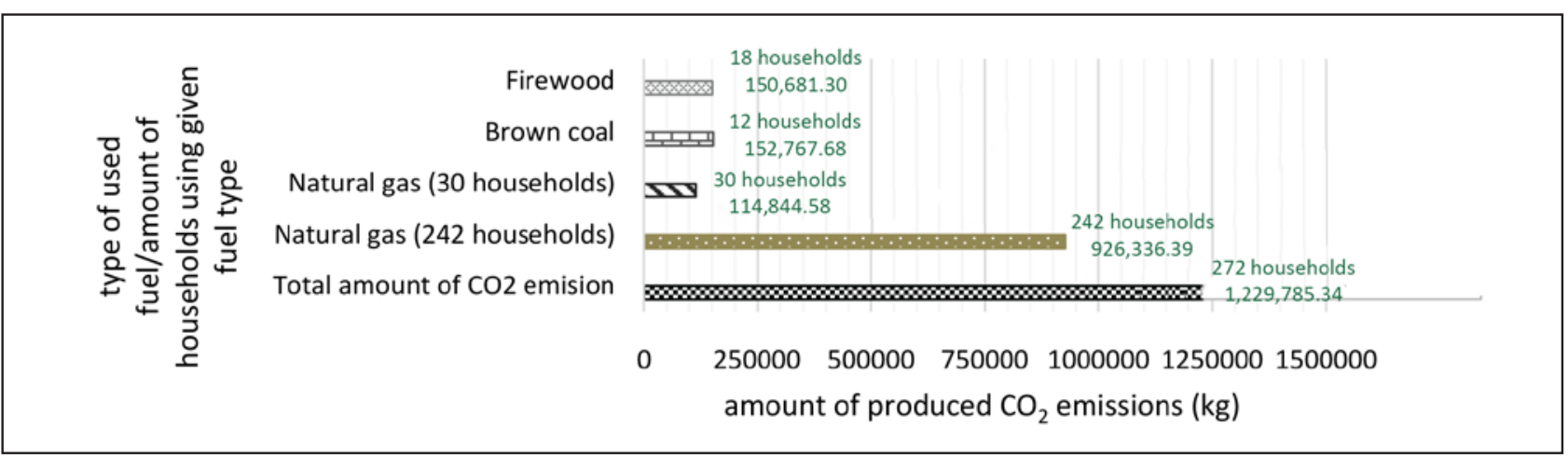

Figure 2 Average amount of $\mathrm{CO}_{2}$ emissions produced by heating process during a heating season per household

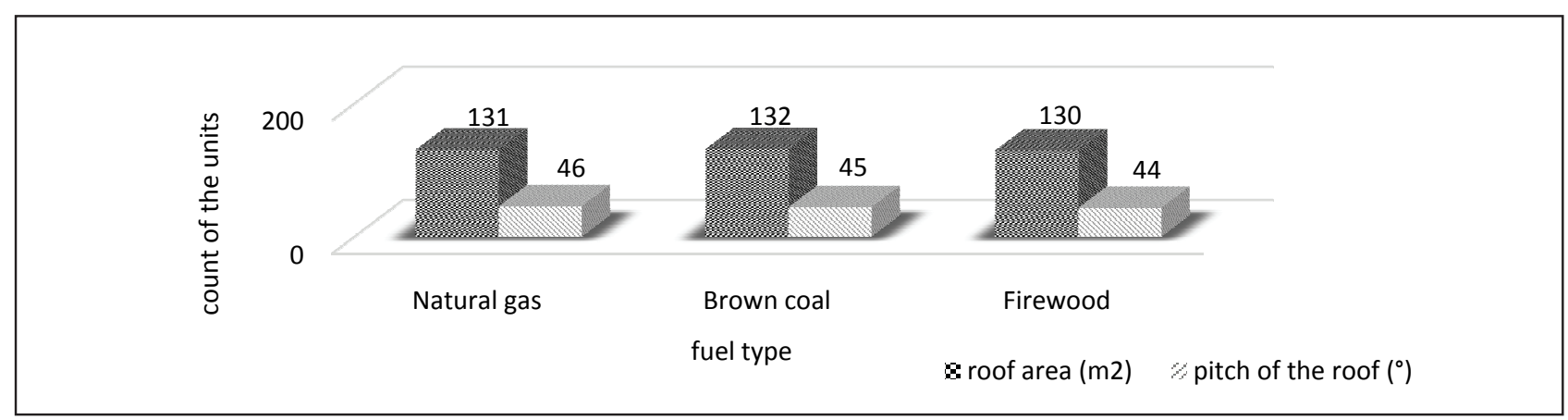

Figure 3 Average roof areas and pitch of roofs

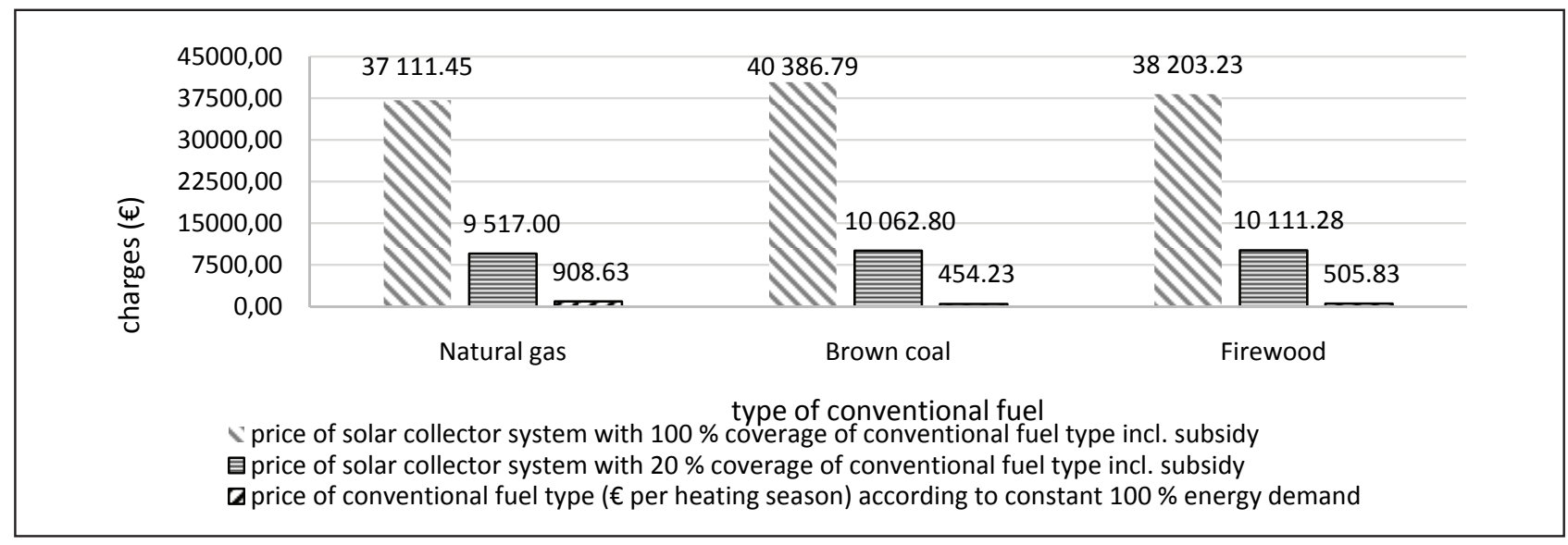

Figure 4 Comparison of financial demands of heating methods

average, $150,681.30 \mathrm{~kg}$ of $\mathrm{CO}_{2}$ emission are produced by households using firewood.

In case of installation of solar collectors, roof parameters in household and orientation of roof surface (S, SE, SW), pitch of the roof and roof area need to be considered. This is necessary to reach the ideal efficiency of solar collectors. The results in Figure 3 show average roof areas from $131 \mathrm{~m}^{2}$ in households using natural gas, $132 \mathrm{~m}^{2}$ in households using brown coal, and finally $130 \mathrm{~m}^{2}$ in households using firewood. Average pitch of the roofs varied from $46^{\circ}$ in households using natural gas to $44^{\circ}$ in households using firewood. Households using brown coal own roofs with average pitch of $45^{\circ}$.

Considering the average consumption in case of each conventional fuel type it is possible to talk about financial demands shown in Figure 4, where the collector systems replacing $100 \%$ of conventional fuel would cost $37,111.45 €$ in case of natural gas, 40,386.79 $€$ for brown coal, and $38,203.23 €$ in case of households using firewood. Price of collector system covering $20 \%$ of conventional fuel type consumption would be $9,517 €$ in case of replacing natural gas, $10,062.80 €$ for brown coal, and finally, 10,111.28 $€$ in case of replacing firewood.

The return of investment of system replacing $100 \%$ conventional fuels (Figure 5) after rounding up represents 41 year for natural gas, 89 years for brown coal, and 75 years for firewood. In case of $20 \%$ replacement these would constitute 52, 111 and 100 years.

In case of the suggested collector system it seems that each alternative of replacement of conventional fuel type 


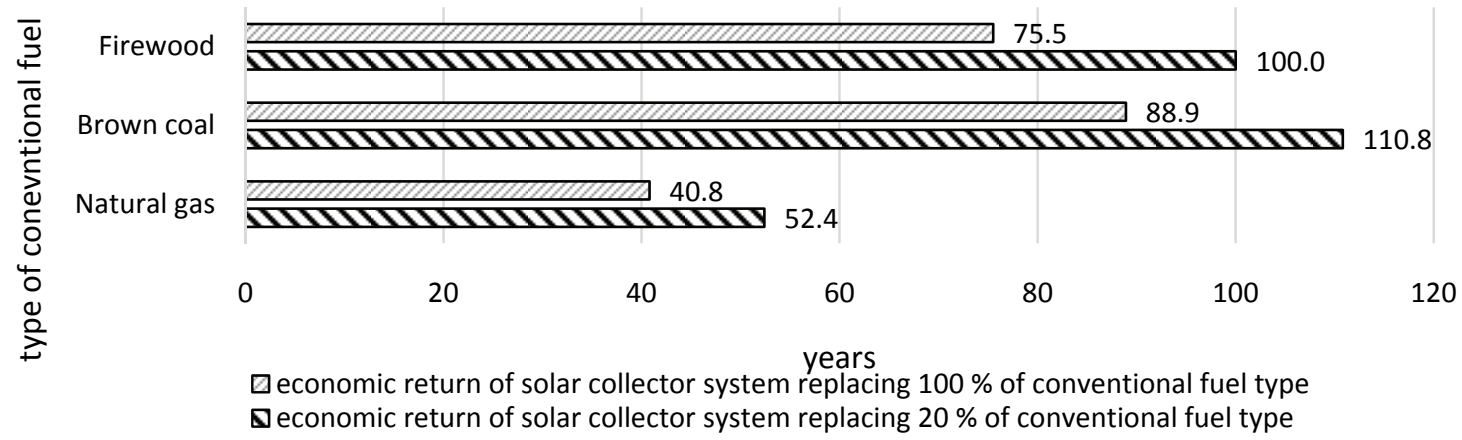

Figure 5 Economic return of proposed solar collector systems

is ineffective according to actual fuel prices, as well as energetic effective accessory of households. The solution may be an extension of exploitation of collector system for pool heating, or preparing domestic hot water (DHW) during all year.

It should be also pointed out that the calculations did not take into account the future trend of prices of conventional fuels, i.e. mainly increase of the price per unit of fuel, as well as technological progress linked to solar technologies. This may change quality, cost decrease demand of collectors production, as well as extend collector lifetime. Thus, the current payback could be more realistic and it could bring benefits for multigenerational households in the form of saved funds.

Also, there is an important question of financial demand. Price of each of the mentioned collector systems is too high in comparing with monthly salary of villagers. Average age of people living in households is approximately 39. In general, each family, besides adults in productive age, consists of children or old people in retirement age. The main barrier towards the use of collector systems is poor financial situation in the village, with exception of the socially stronger families whose members are successful businessmen, or their life style does not require higher economical demand.

It is also possible to think about the decrease of the price of collector systems due to the increasing competition at the European and worldwide market, new comparable or improved products along the technology side for water heating and households heating. This concerns not only extending of the life of collector system parts, but also reducing the production costs (e.g. using much cheaper materials), maintenance costs, or collector efficiency increase. The mentioned facts would shorten the time horizon for investment return of the proposed solar system for each household in the area of interest. However, it is not possible to confirm this idea.

Another point of view is mostly environmental. Nowadays, the idea of protecting environment and natural sources is a crucial one. According to the information about the horizon of current nonrenewable sources it is necessary to speak about such solutions that could refute all of current doubts. This paper says about a solution which could be applied in much wider area that the research mentions. However, considering the effectiveness amount, solar energy is capable in most regions round the world. Only one issue could pose a barrier to the use of modern solar technology financial situation. Therefore, it will be advisable to make highlighted financial support for households which would prefer this kind of technology use for their own and make some action to decrease the emissions causing negative impact on the Earth.

\section{Conclusion}

According to the questionnaire data, it was possible to calculate the amounts of households' consumption of each fuel type in form of energy demand. Then, it was possible to draft solar collector system covering $100 \%$ and $20 \%$ of energy demand of household for heating purposes using conventional types of fuel. Findings of this research can be used for the following purposes:

- decrease of overall amount or total elimination of inadequate isolations of houses,

- reduction or complete removal of inept practices/ usage in case of heating process and draft of possible solutions for situation improvement,

- elimination of health concerns, mostly respiration diseases, because of solid pollutants emitted in heating process (in case of using solid fuel types),

- decrease of environment impact by reduction or complete elimination of $\mathrm{CO}_{2}$ emissions production,

- improvement of microclimate conditions in regions and complete elimination of solid pollutants (in case of using solid fuel types),

- decrease of consumption of the natural sources of which amounts are reduced,

- fulfillment of commitments to the European Union in the case of gross final consumption of energy using renewable energy sources (Chrást, 2004; Resch, 2010),

- keeping pace with technological advances provided by maturity of the present,

- reduction of global problem in the case of active greenhouse gas emissions and reduction of the possibility of increasing ozone hole (research is aimed only at small area, which could be applied on much bigger regions or states round the world).

This work should be the source of information about current consumption of used conventional fuels in surveyed households. The quantity of $\mathrm{CO}_{2}$ emission emitted during 
heating process into atmosphere should also be noticed. The acquired data with calculations relate only to the small village with less than 800 of inhabitants. Therefore, it is necessary to highlight the idea of the possible use of renewable resources of energy focused on much bigger area. Based on these principles, it is possible to improve the situation in global scale, in term of quantities of emitting greenhouse gases, reducing the risk of expansion of the ozone layer, as well as decreasing of population diseases.

\section{References}

BOŽIKOVÁ, M. 2012. Obnovitel'né zdroje energie v teórii a praxi : slnečná energia a veterná energia. 1. vyd. Nitra : SPU, 2012. 150 s. ISBN 978-80-552-0843-5.

BRESTENSKÝ a i. 2009. Objemová hmotnost’ najčastejšie prepravovaných materiálov $\mathrm{v}$ pol'nohospodárstve. [online]. 2009, [cit. 2013-01-16]. Available at: <http://www. agroporadenstvo.sk/zv/ostatne/objemhm.htm>.

CENAE. 2013. Zloženie koncovej ceny. [online]. 2013, [cit. 201302-05]. Available at: <http://www.cenaenergie.sk/>.

DUFFIE, J. et al. 1991. Solar Engineering of Thermal Processes. $2^{\text {nd }}$ edition. New York : John Wiley \& Sons, Inc, 1991. 944 p. ISBN 0-471-51056-4.

HBP. 2013. Katalóg uhlia Hornonitrianskych baní Prievidza, a. s. pre rok 2013. [online]. 2013 [cit. 2013-02-08]. Available at: <http://www.hbp.sk/uploads/images/produkty/Katal\%C3\% B3g\%20uhlia\%202013.xls>.

HORVÁTH, T. 2013. Cena uhlia - Ipel'ský Sokolec [e-mail]. Správa pre: Matej HUDEC. 2013-01-21 [cit. 2013-02-07]. Personal communication.

CHRÁST, R. a i. 2004. Identifikácia priorít a rozvoja kapacít pre plnenie záväzkov SR vyplývajúcich z globálnych environmentálnych dohovorov: Tematická hodnotiaca správa o potrebných rozvoja kapacít pre Rámcový dohovor OSN o zmene klímy. Bratislava : MŽP SR, MP SR, UNDP. 2004. 78 s.

JUROVČ́́K. 2008. Palivové drevo. [online]. 2013, [cit. 2013-0208]. Available at: <http://www.jurovcik.sk/produkty-palivove. html>.
LADENER, H. - SPÄTE, F. 2003. Solární zařízení. Praha : Grada, 2003. 268 s. ISBN 80-247-0362-9.

MATUŠKA, T. 2010. Alternativní zdroje energie. Praha : ČVUT, 2010. $119 \mathrm{~s}$.

NBS. 2013. Kurzový lístok ECB - Vývoj EUR k PLN k 3. 2. 2013. [online]. 2013, [cit. 2013-02-03]. Available at: <http://www.nbs. sk/sk/statisticke-udaje/kurzovy-listok/grafy-kurzov>

ORŠULA, J. 2013. Cena uhlia - orech 1 HBP, HBP, a.s. [email]. Message for: Matej HUDEC. 2013-01-21 [cit. 2013-02-07]. Personal communication.

PETRÁŠ, D. A i. 2009. Obnovitelné zdroje energie pre nízkoteplotné systémy. Bratislava : Jaga Group, 2009. 224 s. ISBN 978-80-807-6075-5.

RESCH, G. a i. 2010. Výhladová analýza využívania obnovitel'ných zdrojov energie na Slovensku: analýza. Vienna : Viedenská technická univerzita, Ústav elektrických sietí a energetickej ekonomiky, Energeticko-ekonomická skupina (EEG). 2010. $29 \mathrm{~s}$.

SPP. 2013. Vyberte si pre vás ten najvýhodnejší druh tarify. [online]. 2013 [cit. 2013-02-09]. Available at: <http://www.spp. sk/plyn/domacnosti/ceny-dom/zakladne-cennikove-ceny/>.

WATT2. 2013. WATT CPC 9. [online]. 2013, [cit. 2013-02-03]. Available at: <http://www.watt.pl/pl/produkty/kolektorysloneczne/kolektory-prozniowe/watt-cpc-10.html>.

WATT3. 2013. eWATT MEGA DUO [online]. 2013, [cit. 201302-03]. Available at: <http://www.watt.pl/pl/produkty/wattstandard/zestawy-z-kolektorami-prozniowymi0/ewatt-duomega0.html>.

\section{Contact address:}

Ing. Matej Hudec, Slovak University of Agriculture in Nitra, Faculty of European Studies and Regional Development, Department of Sustainable Development, Mariánska 10, 94901 Nitra, Slovak republic, e-mail: xhudecm2@uniag.sk 